Open Access

\title{
The impacts of corporate social responsibility, service quality, and transparency on relationship quality and customer loyalty in the hotel industry
}

\author{
Sung-Bum Kim ${ }^{1}$ and Dae-Young Kim²
}

\author{
* Correspondence: \\ kimdae@missouri.edu \\ ${ }^{2}$ Hospitality Management, University \\ of Missouri, 115 Eckles Hall, \\ Columbia, MO 65211, USA \\ Full list of author information is \\ available at the end of the article
}

\begin{abstract}
The purpose of this study was to test how potential customers' perceptions of a hotel's corporate social responsibility activities, service quality, and transparency affect relationship quality constructs such as trust, satisfaction, and customer loyalty. Our research design consisted of utilizing a convenience survey of 487American potential hotel customers. We then followed a two-step approach, projecting a measurement model and then analyzing a structural model to test the theoretical relationships between the constructs. The following findings within the context of $U$. S. hotels show: Corporate social responsibility and reputation had positive relationships with trust and satisfaction, while service quality had a direct effect on customer loyalty. In addition, transparency had a significant influence on customer trust. Customer trust had a significantly positive influence on customer loyalty. The influence of satisfaction on customer loyalty is mediated by trust. This research will contribute to scholarly and managerial debates.
\end{abstract}

Keywords: Customer loyalty, Corporate social responsibility, Corporate reputation, Relationship quality, Service quality, Transparency

\section{Introduction}

Competition in the hospitality industry is becoming quite fierce; therefore, maintaining existing customers is a crucial way for hotels to obtain a continuous competitive advantage over other businesses. The hospitality industry continues to seek diverse strategies to improve its brand image and maintain its customer loyalty. Hospitality company leaders have introduced Corporate Social Responsibility (CSR) as a strategy for achieving these goals. However, it is not clear whether these positive impacts explain customer loyalty. Although corporate social responsibility initiatives have yielded positive responses to the company, this may not translate into superior customer allegiance because consumers are hesitant to trade CSR for certain central qualities (Ailawadi et al. 2014).

According to Brown and Dacin (1997), there are two distinct dimensions of corporations: service quality and corporate social responsibility. They claim that consumers use trade-off values between CSR involvement and service quality. Consumers also

(c) The Author(s). 2016 Open Access This article is distributed under the terms of the Creative Commons Attribution 4.0 International License (http://creativecommons.org/licenses/by/4.0/), which permits unrestricted use, distribution, and reproduction in any medium, provided you give appropriate credit to the original author(s) and the source, provide a link to the Creative Commons license, and indicate if changes were made. 
continue to purchase products or services not only for the betterment of society but also for personal reasons. Despite the pervasiveness of moral and ethical standards within contemporary society, Coelho and Henseler 2012 claim that company executives also pay more attention to the effect of service quality on customer behavior because it is more related to corporate profits and performance than CSR. In the competitive world of business, service quality is thought of as a critical tool for improving longterm relationships with customers (Mittal et al. 2015) while CSR relates to societal concerns, or the character of the organization (Luo and Bhattacharya 2006).

Corporate reputation (CR) has been linked to CSR and service quality (Brown and Dacin 1997). Su et al. (Su et al. 2015b) reveal that customer-perceived CSR doings and $\mathrm{CR}$ are two intangible resources that are likely to provide a competitive advantage for a hotel. Fombrun and Shanley (1990) argue for a positive correlation between CR and CSR. Given that CR is an important competitive advantage for a company and that companies must meet the expectations of stakeholders and compete for a positive reputation among consumers to ensure success in a competitive market environment, service quality is tightly linked to corporate reputation (Wirtz et al. 2000).

Company executives who wish to communicate their CSR efforts and activities to stakeholders must create a sense of transparency in order to establish positive relationships with consumers (Reynolds and Yuthas 2008). Corporate social responsibility is closely related to transparency, and transparency is a necessary condition for CSR to thrive (Dubbink et al. 2008). Organization leaders are gradually being required to exhibit greater levels of transparency (Schmitz et al. 2012). However, while company executives outwardly profess a commitment to CSR goals, an insufficient level of information is often disclosed by hospitality company executives through corporate sustainability reporting (Bonilla-Priego et al. 2014; de Grosbois 2012). Major hotels often fail to produce in-depth reports on their CSR efforts and activities Holcomb et al. (2007).

Relationship quality (i.e., trust and satisfaction) should be strengthened to build longterm associations with esteemed customers. Customer satisfaction and trust have partially or fully mediating roles on customer responses (Walsh and Bartikowski 2013b). Lee et al. (2012) examined the effects of satisfaction and trust on behavioral outcomes or customer loyalty (Pérez et al. 2013).

While interest in CSR in the hospitality industry continues to grow, actual understanding of this concept and service quality in the hotel context is limited (Park and Levy 2014). Leaders of hospitality- related firms struggle with negative consumer perceptions of their companies and with a general lack of consumer loyalty (Swimberghe and Wooldridge 2014). Although Kim and Han (2008) demonstrate the effects of trust and customer satisfaction on customer loyalty in the restaurant sector, the connection between these factors and CR have not yet been investigated, and some of the inconsistent results related to the relationships between these factors require further examination. Only scant attention has been given to the status of transparency within the hotel context. We investigated whether or not customer trust and satisfaction could act as bridges between CSR, service quality, corporate reputation, transparency and customer loyalty in a hospitality service context. Thus, the purpose of this research was to examine the effects of corporate social responsibility, service quality, corporate reputation, and transparency on relationship quality (trust and satisfaction) and customer loyalty. 


\section{Literature review \\ CSR and service quality}

Brown and Dacin (1997) claim that all the information a consumer holds about a company consists of CSR and service quality. Perceived CSR refers to a company's commitment to its societal obligations. Detailed CSR information about a company can lead to higher awareness of its activities in this area (Bhattacharya and Sen 2004) and that this type of information is typically beneficial to a company's image (Diehl et al. 2016). Service quality refers to a company's ability to produce or organize. Consumers use the company's service quality and CSR as evaluative criteria for their purchasing decisions (Kolkailah et al. 2012). Auger et al. (2003) clarify the dispute by noting deficiencies in current studies that attempt to rank the significance of CSR issues while avoiding the use of trade-off measures between service quality and CSR product features. Perceived service quality has been found to have a stronger impact on the perceptions of stakeholders than CSR initiatives, while existing studies have shown the opposite effect.

\section{Corporate reputation}

Wang et al. (2003, p. 76) refer to "reputation plays an especially important strategic role in service markets because the pre-purchase evaluation of service quality is necessarily vague and incomplete." In other words, a strong, positive CR is a vital competitive advantage in markets that product differentiation is challenging because it provides leverage for managing consumers (Shamsie 2003). Corporate status can be regarded as a company-centric construct that influences how employees of the organization behave on behalf of it (Ettenson and Knowles 2008). Reputation is defined as the features that differentiate one company from another (Barnett et al. 2006). Corporate reputation can be measured as a necessary strategic resource that contributes to a firm's sustainable competitive advantage.

\section{Transparency}

Transparency has become a buzzword that involves precision, truth, and the full disclosure of pertinent information (Murphy et al. 2007). Transparency is defined as the degree of accessibility of relevant information for consumers, which makes perceived access to information a critical component of alleged transparency (Cicala et al. 2014). As part of an effective CSR communication strategy, each company leader must determine the level of transparency he or she will reveal in these communications (Fernandez-Feijoo et al. 2014). Transparency plays a role in decreasing informational asymmetry and helps to create fair markets and reduce inequalities (Sud and VanSandt 2012).

\section{Relationship quality (satisfaction and trust as mediating variables)}

Relationship quality refers to a customer's assessment of the strength of their relationships with the service providers (Crosby et al. 1990). The goal of relationship marketers is to build long-term relationships with valued customers. Consumer trust is defined as a belief that the product or service provider can be relied on so that the long-term interests of the consumers will be served (Crosby et al. 1990). Trust is one of factors commonly employed to measure company-consumer relationships. Satisfaction has 
been found to be a strong predictor of intention to revisit a service provider in the future and provide positive recommendations and referrals (Can 2014).

\section{Customer loyalty}

Loyalty refers to customers purchase the products they have grown to prefer from a company they trust and will continue to do so in the future, despite diverse situational impacts and marketing efforts to encourage switching behavior (Oliver 1999). As customer loyalty is considered essential to a firm's growth, building a loyal customer base has not only become a major marketing goal (Kotler and Armstrong 2008), it is also an important basis for developing a sustainable competitive advantage (Dick and Basu 1994). Understanding customer loyalty and retention is key to delivering long-term corporate profitability (Reichheld 1996), as profits can be increased over the lifetime of a customer through his or her continued business (Lemon et al. 2002). Marketing scholars and specialists recognize maintaining customer loyalty as an objective in all service industries.

\section{The influence of CSR on customer trust, satisfaction, and loyalty}

The concept of CSR initiatives has been incorporated into the hotel customer loyalty model (de Leaniz and Del Bosque Rodríguez 2015), but few researchers have empirically assessed whether or not it has a direct influence on customer loyalty (e.g., Choi and La 2013). Relevant studies have reported no connection between CSR activities and customer behavioral outcomes (e.g., Vaaland et al. 2008). This idea still requires further examination to determine if CSR is a direct antecedent of loyalty in the hotel industry. Relevant studies have called for further research to investigate relevant mediator variables in CSRcustomer outcome relationships (Walsh and Bartikowski 2013b). Empirical studies show the vital effects of CSR on antecedents (i.e., trust and satisfaction) hotel customer loyalty. Hence, the following hypotheses were proposed:

H1. Perceived corporate social responsibility has a significantly positive influence on overall customer satisfaction.

H2. Perceived corporate social responsibility has a significantly positive influence on overall customer trust.

H3. Perceived presence of corporate social responsibility has a significantly positive influence on customer loyalty.

\section{The influence of service quality on customer satisfaction, trust, and loyalty}

The fact that service quality is a key determinant of customer satisfaction (Orel and Kara 2014) has been confirmed within the hospitality contexts ( $\mathrm{Su}$ et al. 2016). Customer satisfaction has been found to mediate the effect of service quality on customer responses including loyalty ( $\mathrm{Su}$ et al. 2016). Consumer perception of service quality reduces the perceived risk of consumption and helps the customer to more effectively evaluate and build trust with the company (Doney and Cannon 1997). Relationship quality fully mediates the service quality-customer loyalty relationship (Roberts et al. 2003). Therefore, we proposed the following hypotheses: 
H4. Perceived service quality has a significantly positive effect on overall customer satisfaction.

H5. Perceived service quality has a significantly positive effect on overall customer trust.

H6. Perceived service quality has a significantly positive effect on overall customer loyalty.

\section{The influence of CR on customer satisfaction, trust, and customer loyalty}

Corporate reputation is an essential factor for establishing customer relationships (Wu et al. 2012). Existing studies indicate that a sense of trust and satisfaction in a corporation is a result of good CR (Keh and Xie 2009), while others treat reputation as an outcome of these factors (Walsh et al. 2009). Corporate reputation is associated with key marketing outcomes, such as trust, satisfaction, and loyalty (Roberts and Dowling 2002). A good reputation has the ability to reduce uncertainty and create a sense of trust for consumers (Smaiziene 2008). The influence of CR on customer loyalty is fully mediated by customer satisfaction (Loureiro and Kastenholz 2011). Earlier investigators found that CR can directly affect customer satisfaction and lead to customer loyalty (Loureiro and Kastenholz 2011). When hotel customers are impressed by its reputation, positive behavioral intentions and customer loyalty increase towards the hotel. Therefore, we hypothesized the following:

H7. Corporate reputation has a significantly positive influence on overall customer satisfaction.

H8. Corporate reputation has a significantly positive influence on overall customer trust.

H9. Corporate reputation has a significantly positive influence on customer loyalty.

\section{The influence of transparency on customer trust, satisfaction, and loyalty}

Transparency strengthens the customer-company relationship (Waddock 2004). Increasing a company's transparency can affect not only the association between corporations but also their consumer's perceptions (Kang and Hustvedt 2014), which is consistent with previous research stating that transparency is positively related to generation of trust (Medina and Rufín 2015). Empirical studies (Gainey and Klaas 2003) have reported a positive relationship between transparency, trust and satisfaction. Transparency is positively linked with customers' behavioral intentions (Liu et al. 2015). Therefore, we stated the following hypotheses:

H10. Transparency has a significantly positive influence on overall customer satisfaction.

H11. Transparency has a significantly positive influence on overall customer trust.

H12. Transparency has a significantly positive influence on customer loyalty.

\section{The relationship between customer trust and satisfaction and its effect on customer} loyalty

Trust and satisfaction are integral for building and maintaining long-term relationships and enhancing customer loyalty, which plays a crucial role in relationship marketing research, especially in the hospitality marketing literature. Existing studies confirmed that customer satisfaction and trust have a positive effect on customer loyalty (Hyun 2010). 
Horppu et al. (2008) propose that satisfaction precedes trust and positively affects it. Thus, we proposed the following hypotheses:

H13. Overall customer satisfaction has a significantly positive influence on customer trust.

H14. Overall customer satisfaction has a significantly positive influence on customer loyalty.

H15. Overall customer trust has a significantly positive influence on customer loyalty.

Figure 1 presents a causal and integrated model that summarizes the predicted relationships between the variables. Links between CSR, service quality, corporate reputation, and CSR-related transparency and the effects of trust and satisfaction on customer loyalty within the hotel context are all incorporated into the model.

\section{Research methodology}

Measures and development of the questionnaire

A preliminary list of measurement items for the current study was adapted from the existing literature. We measured all items using a five-point Likert-type scale, ranging from strongly disagree (1) to strongly agree (5). Corporate social responsibility was measured via five items adapted from the existing research (Brown and Dacin 1997; Walsh and Bartikowski 2013b) including, "This hotel seems to make an effort to create new jobs." Three service quality items were adapted from Fombrun et al. (2000) and Brown

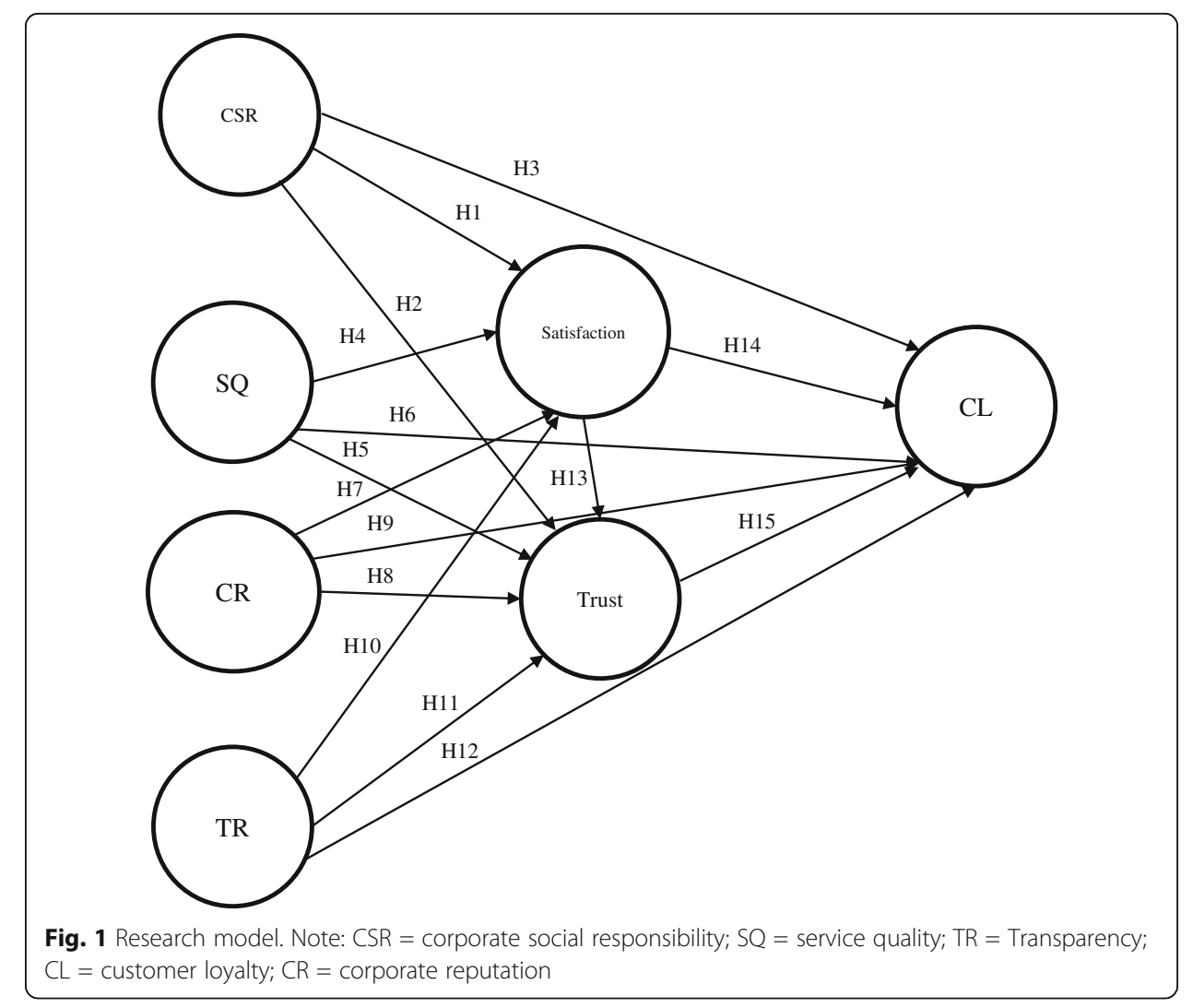


and Dacin (1997) such as "This hotel offers high quality products and services." Perceived CR was measured using three items originally created by Weiss et al. (1999), including items such as, "This hotel is very successful." Five transparency items were measured with a scale to assess consumer perceptions on transparency, as outlined in previous studies (Hustvedt and Kang 2013; Liu et al. 2015). It included questions such as, "It is easy to obtain sufficient information about this hotel's CSR activities."

We measured consumer trust via five items from a scale developed by previous studies (Morgan and Hunt 1994), which included questions such as, "I trust the quality of this hotel." We measured consumer satisfaction via three items developed by Maxham and Netemeyer (2002) including, "As a whole, I am satisfied with this hotel." In order to measure customer loyalty, we utilized a four-item scale, which we borrowed from other relevant studies (Sirdeshmukh et al. 2002). An example question was "This hotel company is my first choice compared to other hotel brands." The questionnaire concluded with a series of demographic questions for identifying the gender, ethnic background, age, level of education, and annual income of our respondents.

Two faculty members and six graduate students of Hospitality Management at MidWest University, in the U. S. reviewed a preliminary questionnaire containing these items. Based on their responses, we adapted it and removed any redundant or vague questions. After designing the questionnaire, we evaluated the internal consistency of each construct through a pilot test with participants $(n=30)$ recruited from Amazon Mechanical Turk to assess the clarity, accuracy, and readability of the survey items.

\section{Data collection}

A hypothetical hotel was mentioned in the questionnaire description to reduce participant biases, such as pre-existing attitudes about or loyalty to a certain brand or company, which may occur when a real company or brand is used. The hypothetical description was developed from previous relevant studies (e.g., Zhang and Mattila 2015). We clearly stated in the introduction of the survey that participants' responses would be treated anonymously, kept confidential, and would be used for academic purposes only. We also explained that there were no right or wrong answers and that we were merely interested in participants' honest impressions. In order to test our conceptual model, we conducted an online survey among U.S. citizens. Qualified participants were instructed to evaluate their previous experiences at hotels. Participants were required to be at least18 years old and live in the United States at the time of the survey. We collected 500 questionnaires in total from Amazon Mechanical Turk, thirteen of which were thrown out because of inert, simulated answer patterns, or incompletion. Thus, the 487 remaining questionnaires were sufficient for data analysis.

\section{Sample profile}

The demographic profile of respondents is presented in Table 1. Males represented $49.1 \%$, and females represented $50.9 \%$ of the sample. Respondents aged 25-34 accounted for $48.3 \%$ of the sample; the next largest age group was between 35 and 44 years (25.1\%). Respondents' ethnicity was primarily White/Caucasian (79.7\%), followed by Asian (7.0\%) and African American (6.4\%). Nearly 16\% of the 
Table 1 Profile of survey respondents $(N=487)$

\begin{tabular}{|c|c|c|c|}
\hline Demographic characteristics & Descriptive & Frequency & Percentage \\
\hline \multirow[t]{2}{*}{ Gender } & Female & 239 & 49.1 \\
\hline & Male & 248 & 50.9 \\
\hline \multirow[t]{6}{*}{$\mathrm{Age}^{\mathrm{a}}$} & $18-24$ & 38 & 7.8 \\
\hline & $25-34$ & 235 & 48.3 \\
\hline & $35-44$ & 122 & 25.1 \\
\hline & $45-54$ & 52 & 10.7 \\
\hline & $55-64$ & 28 & 5.7 \\
\hline & Over 65 & 12 & 2.5 \\
\hline Education & High school or less & 61 & 12.5 \\
\hline \multirow[t]{3}{*}{ level } & $\begin{array}{l}\text { Some college or associate } \\
\text { ( } 2 \text { year) degree }\end{array}$ & 209 & 42.9 \\
\hline & Baccalaureate (4 year) degree & 178 & 36.6 \\
\hline & Graduate studies/post-graduate studies & 39 & 8.0 \\
\hline \multirow[t]{7}{*}{ Race } & White/Caucasian & 388 & 79.7 \\
\hline & Asian & 34 & 7.0 \\
\hline & African American & 31 & 6.4 \\
\hline & Hispanic/Latino American & 16 & 3.3 \\
\hline & American Indian/Native American & 4 & .8 \\
\hline & Pacific Islander & 1 & .2 \\
\hline & Other & 13 & 2.7 \\
\hline \multirow[t]{10}{*}{ Annual household income ${ }^{b}$ (2015) } & $\$ 0-19,999$ & 81 & 16.6 \\
\hline & $\$ 20,000-29,999$ & 62 & 12.7 \\
\hline & $\$ 30,000-39,999$ & 79 & 16.2 \\
\hline & $\$ 40,000-49,999$ & 48 & 9.9 \\
\hline & $\$ 50,000-59,999$ & 65 & 13.3 \\
\hline & $\$ 60,000-69,999$ & 50 & 10.3 \\
\hline & $\$ 70,000-79,999$ & 32 & 6.6 \\
\hline & $\$ 80,000-89,999$ & 21 & 4.3 \\
\hline & $\$ 90,000-99,999$ & 13 & 2.7 \\
\hline & Over $\$ 100,000$ & 36 & 7.4 \\
\hline
\end{tabular}

Note: ${ }^{a}$ years old; ${ }^{\text {b U.S. Dollars }}$

respondents earned \$30,000-39,999/year. Approximately 42.9\% of respondents had some college education or an associate's (two-year) degree.

\section{Data analysis}

Following Anderson and Gerbing (1988), we adopted a two-step approach, which consisted of utilizing measurement models and then conducting structural equation modeling. To check the reliability and validity of the measurement model, we performed confirmatory factor analysis (CFA) using AMOS. Then, we assessed the simultaneity of all the hypothesized associations among the multiple constructs via structural equation modeling.

The measurement model and validity testing

As seen in Table 2 , the CFA results showed that this model closely fit the data $\left(\chi^{2}=\right.$ $1376.434, d f=303, p<.001), \mathrm{CFI}=.90, \mathrm{IFI}=.90$, and $\mathrm{RMSEA}=.08$. One item from 
Table 2 Item measurement properties

\begin{tabular}{|c|c|c|c|c|c|}
\hline Constructs & Items & Standardized factor loadings & Cronbach's a & $C R$ & AVE \\
\hline \multirow[t]{5}{*}{$\mathrm{CR}$} & CSR_1 & .576 & .825 & .898 & .643 \\
\hline & CSR_2 & .663 & & & \\
\hline & CSR_3 & .831 & & & \\
\hline & CSR_4 & .815 & & & \\
\hline & CSR_5 & .667 & & & \\
\hline \multirow[t]{3}{*}{ SQ } & SQ_1 & .813 & .814 & .810 & .756 \\
\hline & SQ_2 & .808 & & & \\
\hline & SQ_3 & .715 & & & \\
\hline \multirow[t]{3}{*}{$C R$} & CR_1 & .849 & .893 & .897 & .882 \\
\hline & CR_2 & .878 & & & \\
\hline & CR_3 & .846 & & & \\
\hline \multirow[t]{5}{*}{ TR } & TR_1 & .709 & .853 & .726 & .661 \\
\hline & TR_2 & .729 & & & \\
\hline & TR_3 & .753 & & & \\
\hline & TR_4 & .729 & & & \\
\hline & TR_5 & .780 & & & \\
\hline \multirow[t]{3}{*}{ SATIS } & SATIS_1 & .863 & .930 & .991 & .917 \\
\hline & SATIS_2 & .900 & & & \\
\hline & SATIS_3 & .958 & & & \\
\hline \multirow[t]{5}{*}{ TRU } & TRU_1 & .743 & .879 & .795 & .749 \\
\hline & TRU_2 & .814 & & & \\
\hline & TRU_3 & .732 & & & \\
\hline & TRU_4 & .741 & & & \\
\hline & TRU_5 & .814 & & & \\
\hline \multirow[t]{4}{*}{$\mathrm{CL}$} & $\mathrm{CL}_{-} 1$ & .789 & .865 & .922 & .798 \\
\hline & $C L \_2^{a}$ & & & & \\
\hline & CL_3 & .830 & & & \\
\hline & $C_{-}{ }^{4}$ & .862 & & & \\
\hline
\end{tabular}

customer loyalty that had factor loadings lower than .5 was dropped to maintain the proper level of discriminant and convergent validity. Cronbach's alpha values ranged from .814 to .930 , all higher than the commonly recommended .70 value. To evaluate the internal consistency of the multi-item measures for each construct, we conducted a composite-reliability test. All values, which ranged from .726 to .991 , were greater than the recommended threshold of .60 (Bagozzi and Yi 1988). These results suggest satisfactory latent construct reliability. Convergent validity was also acceptable. The convergent validity was evident in that all AVEs were greater than .50. The loading was statistically significant and greater than .50. We assessed the discriminant validity, shown in Table 3, by comparing the AVE values to the square of the correlations between each pair of constructs (Fornell and Larcker 1981). All investigated constructs met the discriminant validity requirement. 
Table 3 Construct intercorrelations

\begin{tabular}{|c|c|c|c|c|c|c|c|}
\hline & 1 & 2 & 3 & 4 & 5 & 6 & 7 \\
\hline 1. CSR & 1 & & & & & & \\
\hline 2. SQ & .782 & 1 & & & & & \\
\hline 3. $C R$ & .696 & .814 & 1 & & & & \\
\hline 4. TR & .800 & .619 & .587 & 1 & & & \\
\hline 5. SATIS & .681 & .693 & .697 & .586 & 1 & & \\
\hline 6. TRU & .863 & .800 & .776 & .784 & .805 & 1 & \\
\hline 7. CL & .737 & .738 & 640 & .674 & .726 & .797 & 1 \\
\hline
\end{tabular}

Note: All coefficients were significant at $p<.05$

$C A$ corporate ability, CSR corporate social responsibility, SQ service quality, CR Corporate reputation, $T R$ transparency, SATIS satisfaction, TRU trust, CL customer loyalty

\section{Structural equation modeling and testing of the hypotheses}

A SEM with a maximum likelihood estimation method was run. Findings from this model indicated a suitable fitness of the projected theoretical model to the data $\left(\chi^{2}=1376.434, d f=303, p<.001\right), \quad$ RMSEA $=.08, \quad$ CFI $=.900$, NFI $=.901$, TLI $=.902$. The squared multiple correlation $\left(S M C ; R^{2}\right)$ statistics of the structural equations for trust and customer loyalty were .869 (86.9\%), and .693 (69.3\%), respectively. We tested the hypothesized associations based on the structural model results. When we assessed hypotheses 1,2 , and 3 , we found that CSR had a positive effect on satisfaction $(\beta=.257, t=2.345, p<.05)$ and trust $(\beta=.337, t=3.869, p<.001)$. However, hypothesis 3 was not supported $(\beta=.057, t=.411)$. Our results also did not support hypotheses 4 and $5(\beta=.199, t=1.936 ; \beta=.109, t=1.393$, respectively). Interestingly, we found service quality to be a positive predictor of customer loyalty, which supported hypothesis $6(\beta=.383, t=3.212, p<.001)$. Thus, while hypotheses 7 and 8 were supported $(\beta=.353, t=4.401, p<.001 ; \beta=.155, t=2.498$, $p<.05$ respectively), hypothesis 9 was not supported $(\beta=-.168, t=-1.758)$.

Transparency, tested in hypothesis 11 , was found to have a positive effect on overall customer trust $(\beta=.239, t=3.842, p=.001)$; however, hypotheses 10 and 12 were not supported $(\beta=.100, t=.080 ; \beta=.179, t=1.855$, respectively). When hypotheses 13,14 , and 15 were tested, results indicated that customer trust exerted a positive impact on customer loyalty $(\beta=.297, t=6.827, p<.001 ; \beta=.279, t=3.669, p<.001 ; \beta=.358, t=$ $2.335, p<.05)$. Our research supports these hypotheses. Table 4 and Fig. 2 show whether or not each hypothesis was supported. It indicates a possible partial mediating role for customer trust between customer satisfaction and customer loyalty. A bootstrap analysis further confirmed the mediating role of customer trust, shown in Table 5. Based on statistically significant results, the paths of CSR and transparency to customer trust and, in turn, to customer loyalty were very clear.

\section{Discussion and implications}

The objective of this research was to determine whether CSR, service quality, corporate reputation, and transparency have an impact on trust and satisfaction on customer loyalty within the hotel industry. The second objective was to examine the relationship between customer loyalty and trust and satisfaction, within the context of the hospitality industry. 
Table 4 Standardized parameter estimates for the structural model

\begin{tabular}{lllll}
\hline Paths & Standardized estimate & SE & $t$-value & Hypothesis \\
\hline H1 CSR $\rightarrow$ customer satisfaction & .257 & .110 & $2.345^{*}$ & Supported \\
H2 CSR $\rightarrow$ customer trust & .337 & .087 & $3.869^{* * *}$ & Supported \\
H3 CSR customer loyalty & .057 & .138 & .411 & Not supported \\
H4 SQ $\rightarrow$ customer satisfaction & .199 & .103 & 1.936 & Not supported \\
H5 SQ $\rightarrow$ customer trust & .109 & .078 & 1.393 & Not supported \\
H6 SQ $\rightarrow$ customer loyalty & .383 & .119 & $3.212^{* * *}$ & Supported \\
H7 CR $\rightarrow$ customer satisfaction & .353 & .080 & $4.401^{* * *}$ & Supported \\
H8 CR $\rightarrow$ customer trust & .155 & .062 & $2.498^{*}$ & Supported \\
H9 CR $\rightarrow$ customer loyalty & -.168 & .095 & -1.758 & Not supported \\
H10 Transparency $\rightarrow$ customer satisfaction & .100 & .080 & 1.251 & Not supported \\
H11 Transparency $\rightarrow$ customer trust & .239 & .062 & $3.842^{* * *}$ & Supported \\
H12 Transparency $\rightarrow$ customer loyalty & .179 & .097 & 1.855 & Not supported \\
H13 Customer satisfaction $\rightarrow$ customer trust & .297 & .043 & $6.827^{* * *}$ & Supported \\
H14 Customer satisfaction $\rightarrow$ customer loyalty & .279 & .076 & $3.669^{* * *}$ & Supported \\
H15 Customer trust $\rightarrow$ customer loyalty & .358 & .153 & $2.335^{*}$ & Supported \\
\hline
\end{tabular}

Goodness-of-fit statistics for the structural model: $X^{2}=1376.434, \mathrm{df}=303, p<.001, \mathrm{RMSEA}=.08, \mathrm{CFI}=.900, \mathrm{NFI}=.901$, $\mathrm{TLI}=.902$

Note: CSR corporate social responsibility, SQ service quality, $C R$ Corporate reputation ${ }^{*} p<.05 ;{ }^{* * *} p<.001$

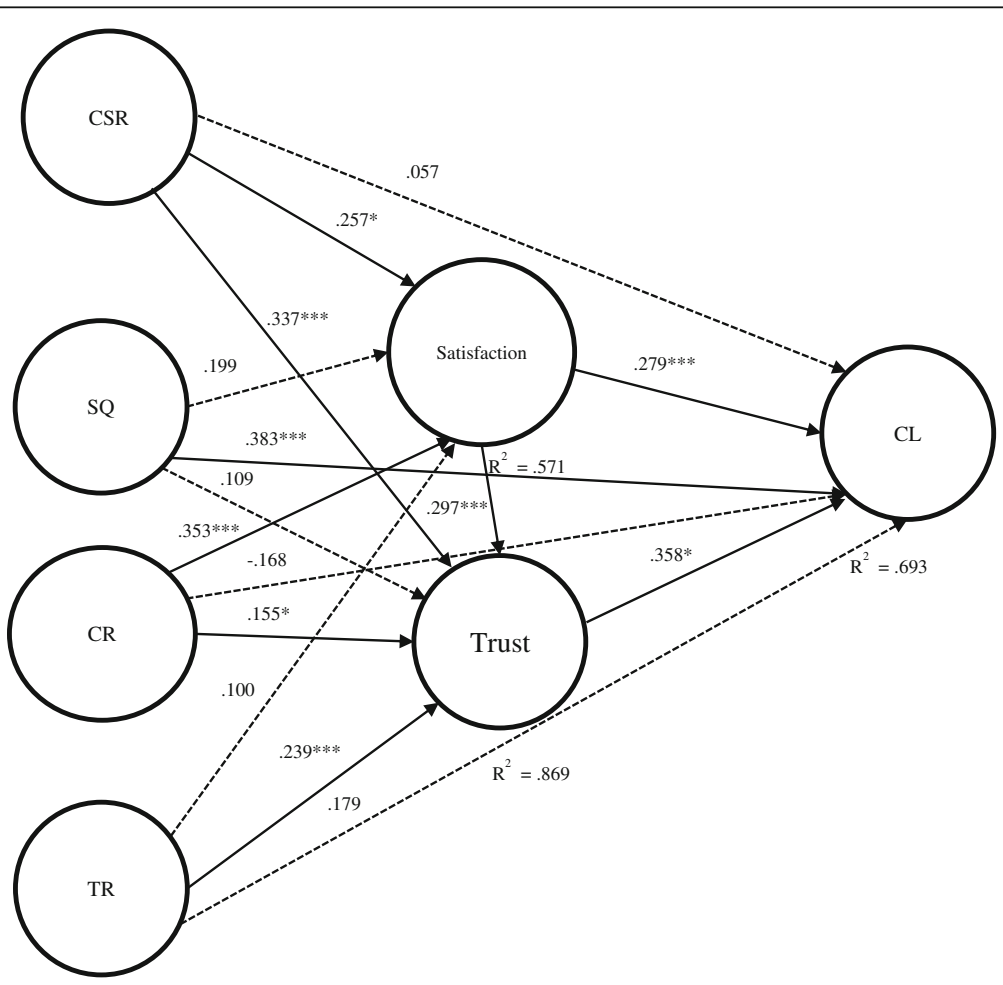

Fig. 2 Structural-model results. Note: ${ }^{*} p<.05 ;{ }^{* * *} p<.001$. Dotted lines indicate non-significant paths. $C S R=$ corporate social responsibility; $S Q=$ service quality; $C R=$ corporate reputation; $\mathrm{TR}=$ transparency; $\mathrm{CL}=$ customer loyalty 
Table $\mathbf{5}$ The mediation role of customer trust: A Bootstrap analysis

\begin{tabular}{lllll}
\hline Mediator & Relationship & Partial mediation & Direct effect size & Indirect effect size \\
\hline Customer trust & $\begin{array}{l}\text { Customer satisfaction } \rightarrow \text { customer } \\
\text { loyalty }\end{array}$ & $\sqrt{ }$ & .244 & .093 \\
\hline
\end{tabular}

Note: With regard to the Customer satisfaction $\rightarrow$ customer trust $\rightarrow$ customer loyalty relationship, the total effect (.337) is decomposed into direct effect (.244) and indirect effect (.093)

Relevant studies have determined that corporate social responsibility can impact consumer assessments by improving the company's image and trustworthiness and increasing customer satisfaction (Wan et al. 2016). Relevant studies indicate that CSR initiatives should involve a frank long-term effort to build customer trust (Choi and La 2013). In terms of hypotheses 1, 2, and 3, unlike existing studies (e.g., Su et al. 2015b), our findings indicated that CSR did not directly influence customer loyalty. By showing that a company's CSR initiatives could increase customer satisfaction, Luo and Bhattacharya (2006) found a direct relationship between CSR and customer satisfaction A company's positive image, reflected in its CSR activities, that has been established through advertising may not necessarily translate into actual intentions or increased loyalty toward a company or its product/service on the part of consumers (Chernev and Blair 2015). While CSR initiatives produce high levels of satisfaction and trust, it remains unclear as to whether the positive effects translate into customer loyalty because consumers are reluctant to trade off CSR for core attributes. In terms of hypotheses 4, 5, and 6, we found a direct connection between service quality and loyalty. Our research showed that improving service quality in a meaningful way (hypothesis 6) increases customer loyalty, which has been confirmed in previous investigations.

Based on our findings (hypotheses 7, 8, and 9), developing a positive CR can lead to improved customer satisfaction and eventually result in raised intentions of customer loyalty. Walsh et al. (2009) found a link between perceived CR and customer loyalty (Walsh et al. 2009). As such, fostering a good reputation can involve cost outlays in both the short term and long term, as suggested by Su et al. (2015a). Hypotheses 10 and 12, the concepts that transparency has a positive influence on customer loyalty, were not supported. In terms of hypothesis 11, the results of this work enabled us to verify that transparency is positively linked to building trust, which is in line with earlier works (Medina and Rufín 2015). Kang and Hustvedt (2014) emphasize the essential role of trust, involving consumer perceptions of transparency, for obtaining a more complete understanding of consumer loyalty behavior. In terms of hypotheses 13, 14, and 15, our findings suggested that trust also had an important effect on the development of customer loyalty within the sector. In addition, our findings (hypotheses 13, 14, and 15) indicated that hotels should strive to cultivate customer trust in order to establish high quality relationships. Hotel managers should design strategies to improve customer perception of corporate image and help guests to develop greater levels of trust to ultimately encourage enduring relationships with companies.

\section{Theoretical implications}

Our findings have considerable theoretical and practical implications for this field. From a theoretical perspective, while CSR has been investigated extensively, our 
research presents valuable implications by extending the existing model (Brown and Dacin 1997) to include transparency and corporate reputation. Our investigation contributes to the literature by examining the variables (i.e., trust and satisfaction) that mediate the link between CSR and customer loyalty.

Although CSR is believed to enhance the trustworthiness and likability of a business (Klein and Dawar 2004), these findings are not directly relevant to evaluating customer responses to service offerings. The literature on the relationship between CSR and customer satisfaction does not always support a significantly positive relationship. Previous studies have examined the relationships between the perception of service quality, customer satisfaction, and behavioral intentions (Su et al. 2016). Although current studies indicate that customer satisfaction has a partial mediating role (e.g., Dagger and Sweeney 2006; Walsh and Bartikowski 2013b), we found that customer satisfaction had a fully mediating effect on both service quality and customer loyalty. The relevant studies regarding the impact of transparency on individuals' trust have shown mixed findings. The causal relationship between CR and trust or customer satisfaction remains unclear within the hotel context (Park et al. 2014). Bontis et al. (2007) point out that more research is needed to understand the relationship between customer satisfaction and corporate reputation. A conceptual model of antecedents and outcomes of CR, which has yet to be tested against empirical data (Walsh and Wiedmann 2004). Su et al. (2015a) also claims that modest attention has been paid to the status of CR in a hospitality context. Especially, we determined that CR as a predictor was positively correlated with customer trust and satisfaction. This study provided a model that will add to our understanding of how $\mathrm{CR}$ contributes to relationship building. Thus, the proposed model not only includes antecedents of customer loyalty but also demonstrates a framework of relationships among these constructs that allows for a better understanding of how customers develop a sense of loyalty toward a company.

In this study, we introduced and applied the concept of transparency to customercompany relationships and provided thought-provoking insights for theory building within the hotel industry. Although transparency is not generally considered a variable, as Gutierrez-Nieto and Serrano-Cinca (2010) suggest, such extension is meaningful because previous studies were limited to the exploration of the impact of service quality on CSR, CSR by itself (de Leaniz and del Bosque Rodríguez 2015), and the impact of CSR (Su et al. 2015a) on customer loyalty within the hospitality context.

\section{Practical implications}

From a practical perspective, regarding hypotheses 1, 2, and 3, we found that an unremitting effort to be a good citizen via strategic CSR initiatives will augment long-term relationship quality, which may in turn encourage long-term success (Swimberghe and Wooldridge 2014). Our study confirmed that CSR initiatives are no longer optional and that engagement in CSR activities should be a part of the hotel industry's long-term strategic mission. CSR activities are more likely to lead to positive effects when they are considered trustworthy by consumers. Based on the findings of hypotheses 4, 5, and 6 , increasingly aggressive competition requires hotel company executives to enhance quality (Gray et al. 2000), which is a crucial factor in finding a viable lead and market difference because customer perceptions of service quality directly increases loyalty toward 
the hotel. Thus, hospitality managers still need to heavily invest in improving and maintaining service quality to achieve sustainable competitive advantages. For example, in service businesses well-trained staff with good manners and a high level of expertise play an significant role in boosting consumer loyalty to a particular service or brand.

According to hypotheses 7, 8, and 9, company leaders should closely watch their reputations, as this aspect plays a serious role in the general appraisal of the company. Service companies can profit from the effects of good CR due to the halo effect that encourages customers to have more positive assessments of the company. Good reputation, which has a long-term effect on a firm, is difficult to establish and easy to lose (Fatma et al. 2015). Thus, based on our findings hospitality industry managers should implement $\mathrm{CR}$ as an intangible resource to help provide competitive advantage in the marketplace.

According to hypotheses 10,11, and 12, an effort to be transparent and honest plays an important role in helping a hotel appear more trustworthy and favorably perceived by customers. Mohr et al. (2001) claims that some consumers recognize that although a company may act in a socially responsible manner, this does not necessarily mean that it will be viewed as socially responsible. Consumers are thus not fully informed of companies' behavior (Carrigan and Attalla 2001). Consumer cynicism about the corporate world is increasing, and consumers believe that firms often disperse false and/or misleading environmental information to deceive potential customers and better their image (Parguel et al. 2011). High levels of transparency can be associated with increased confidence in the company's commitment to sustainability (Dando and Swift 2003), resulting in decreasing public doubt about its CSR involvement (Kim and Ferguson, in press). Hospitality managers should reflect on how they are communicating their CSR efforts to potential clients by stressing credibility, transparency, and honesty, and in turn, asking the companies to support their interactive efforts more directly to consumers to increase their trust.

Finally, although existing studies have reported a positive consumer response towards companies engaged in CSR activities, others have discovered that customers are not interested in socially-responsible practices (Vaaland et al. 2008). In fact, they often retain a strong preference for non-socially responsible products in many domains. This failure of CSR to influence patron loyalty has lately been ascribed to consumer uncertainty about CSR efforts like skepticism (Skarmeas and Leonidou 2013). In conclusion, corporate social responsibility is not the most dominant criterion that affects consumer behavior (Boulstridge and Carrigan 2000); service quality, corporate reputation, and CSR-related-transparency remain important standards. This research can help the industry identify the various paths available to establish, improve, or reinforce consumer trust, satisfaction, and loyalty via the constructs discussed above.

\section{Limitations and suggestions for future research}

This study is subject to certain limitations, which are possible areas for future research. First is the probability of social desirability bias in our reported measures. The crosssectional nature of the data limits our ability to draw strong inferences about the sequence of effects. The data used in this research are cross-sectional in nature, which raises concerns about the causal relationships between constructs in the tested model. They could employ a longitudinal design to measure the variables after participants 
discussed their experiences with CSR programs. They could also utilize qualitative research methods, experimental designs, or quasi-experimental designs. Our sample did not represent the entire population in the U.S. It would be helpful if future studies would investigate other types of hospitality establishments, different industries, and other cultures or subcultures in order to increase the generalizability of the findings. Future studies are encouraged to utilize the findings of the present research by extending the model to include other outcomes, antecedents, mediators, and moderators.

\section{Acknowledgement}

There are no acknowledgements.

\section{Authors' contributions}

Researchers at SBK and DYK developed the framework proposed in this research. SBK investigators were also involved in the analysis and the interpretation of the results of this empirical study. All authors read and approved the final manuscript.

\section{Competing interests}

The authors declare that they have no competing interests.

\section{Author details}

${ }^{1}$ College of Business Administration, Inha University, 421B Building \#6, Incheon, South Korea. ${ }^{2}$ Hospitality Management, University of Missouri, 115 Eckles Hall, Columbia, MO 65211, USA.

Received: 3 September 2016 Accepted: 2 November 2016

\section{References}

Ailawadi KL, Neslin SA, Luan YJ, Taylor GA (2014) Does retailer CSR enhance behavioral loyalty? A case for benefit segmentation. Int J Res Mark 31:156-167

Anderson JC, Gerbing DW (1988) Structural equation modeling in practice: A review and recommended two-step approach. Psychol Bull 103:411-423

Auger P, Burke P, Devinney T, Louviere J (2003) What will consumers pay for social product features. J Bus Ethics 42(3): 281-304

Bagozzi RP, Yi Y (1988) On the evaluation of structural equation models. J Acad Mark Sci 16:74-94

Barnett ML, Jermier JM, Lafferty BA (2006) Corporate reputation: The definitional landscape. Corp Rep Rev 9(1):26-38

Bhattacharya CB, Sen S (2004) Doing better at doing good: when, why and how consumers respond to corporate social initiatives. Calif Manage Rev 47(Fall):9-25

Bonilla-Priego MJ, Font X, Pachco-Olivares MDRP (2014) Corporate sustainability reporting index and baseline data for the cruise industry. Tourism Manage 44:149-160

Bontis N, Booker LD, Serenko A (2007) The mediating effect of organizational reputation on customer loyalty and service recommendation in the banking industry. Manage Decis 45:1426-1445

Boulstridge E, Carrigan M (2000) Do consumers really care about corporate responsibility? Highlighting the attitudebehavior gap. J Commun Manag 4(4):355-368

Brown JT, Dacin PA (1997) The company and the product: Corporate associations and consumer product responses. J Mar Sci 61(1):68-84

Can W (2014) Destination loyalty as a consequence of satisfaction and switching barriers. Tour Anal 19(3):273-286

Carrigan M, Attalla A (2001) The myth of the ethical consumer - do ethics matter in purchase behaviour? J Consum Mark 18(7):560-578

Chernev A, Blair S (2015) Doing well by doing good: The benevolent halo of corporate social responsibility. J Cons Res 41:1412-1425

Choi B, La S (2013) The impact of corporate social responsibility (CSR) and customer trust on the restoration of loyalty after service failure and recovery. J Serv Mark Marketing 27(3):223-233

Cicala JE, Bush AJ, Sherrell DL, Deitz GD (2014) Does transparency influence the ethical behavior of salespeople? J Bus Res 67:1787-1795

Coelho PS, Henseler J (2012) Creating customer loyalty through service customization. Eur J Mark 46(3):331-356

Crosby L, Evans KR, Cowles D (1990) Relationship quality in services selling: an interpersonal influence perspective. J Mar Sci 54:68-81

Dagger TS, Sweeney JC (2006) The effect of service evaluations on behavioral intentions and quality of life. J Serv Res $9(1): 3-18$

Dando N, Swift T (2003) Transparency and assurance: Minding the credibility gap. J Bus Ethics 44:195-200

de Grosbois D (2012) Corporate social responsibility reporting by the global hotel industry: Commitment, initiatives and performance. Int J Hosp Manag 31:896-905

de Leaniz PMG, del Bosque Rodríguez IR (2015) Exploring the antecedents of hotel customer loyalty: A social identity perspective. J Hosp Mark Manage 24:1-23

Dick AS, Basu K (1994) Customer loyalty: Toward and integrated conceptual framework. J Acad Mark Sci 22(2):99-113 
Diehl S, Terlutter R, Mueller B (2016) Doing good matters to consumers: the effectiveness of humane-oriented CSR appeals in cross-cultural standardized advertising campaigns. Int J Advert 35(4):730-757

Doney PM, Cannon JP (1997) An examination of the nature of trust in buyer-seller relationships. J Mar Sci 61:35-51

Dubbink W, Graafland J, van Liedekerke L (2008) CSR, transparency and the role of intermediate organisations. J Bus Ethics 82:391-406

Ettenson R, Knowles J (2008) Don't confuse reputation with brand. MIT Sloan Manage Rev 49(2):19-21

Fatma M, Rahman Z, Khan I (2015) Building company reputation and brand equity through CSR: the mediating role of trust. Int J Bank Mark 33(6):840-856

Fernandez-Feijoo B, Romero S, Ruiz S (2014) Effect of stakeholders' pressure on transparency of sustainability reports within the GRI framework. J Bus Ethics 122(1):53-63

Fombrun CJ, Gardberg NA, Sever JW (2000) The reputation quotient: a multi-stakeholder measure of corporate reputation. J Brand Manag 7(4):241-255

Fombrun CJ, Shanley M (1990) What is in a name? Reputation building and corporate strategy. Acad Manag J 33(2): 233-259

Fornell C, Larcker DF (1981) Evaluating structural equation models with unobservable variables and measurement error. J Market Res 18:39-50

Gainey TW, Klaas BS (2003) The outsourcing of training and development: Factors impacting client satisfaction. J Manage 29:207-229

Gray BG, Matear SM, Matheson PK (2000) Improving the performance of hospitality firms. Int J Contemp Hosp M Journal 12(3):149-155

Gutierrez-Nieto B, Serrano-Cinca C (2010) Factors influencing funder loyalty to microfinance institutions. Nonprof Volunt Sec Q 39(2):302-320

Holcomb JL, Upchurch RS, Okumus F (2007) Corporate social responsibility: what are top hotel companies reporting? Int J Contemp Hosp M 19:461-475

Horppu M, Kuivalainen O, Tarkiainen A, Ellonen H (2008) Online satisfaction, trust and loyalty, and the impact of the offline parent brand. J Prod Brand Manag 17(6):403-413

Hustvedt G, Kang J (2013) Consumer perceptions of transparency: a scale development and validation. Fam Consum Sci Res J 41(3):299-313

Hyun SS (2010) Predictors of relationship quality and loyalty in the chain restaurant industry. Cornell Hosp Q 51:251-267

Kang J, Hustvedt G (2014) Building trust between consumers and corporations: The role of consumer perceptions of transparency and social responsibility. J Bus Ethics 125:253-265

Keh HT, Xie Y (2009) Corporate reputation and customer behavioral intentions: The roles of trust, identification and commitment. Ind Market Manag 38(7):732-742

Kim S, Ferguson AT (in press) Dimensions of effective CSR communication based on public expectations. J Mark Commun

Kim W, Han H (2008) Determinants of restaurant customers' loyalty intentions: a mediating effect of relationship quality. J Qual Assur Hosp Tourism 9(3):219-239

Klein J, Dawar N (2004) Corporate social responsibility and consumers attributions and brand evaluations in a product harm crises. Int J Res Mark 21:203-217

Kolkailah SK, Aish EA, Bassiouny N (2012) The impact of corporate social responsibility initiatives on consumers' behavioural intentions. Int J Consum Stud 2:19-35

Kotler P, Armstrong G (2008) Principle of marketing, 12th edn. Pearson Prentice Hall, Upper Saddle River, NJ

Lee Y-K, Kim YS, Lee KH, Li D-X (2012) The impact of CSR on relationship quality and relationship outcomes: A perspective of service employees. Int J Hosp Manag 31:745-756

Lemon K, White T, Winer R (2002) Dynamic customer relationship management: Incorporating future consideration into the service retention decisions. J Mar Sci 66(1):1-14

Liu Y, Eisingerich AB, Auh S, Merlo O, Chun HEH (2015) Service firm performance transparency: How, when, and why does it pay off? J Serv Res 18(4):451-467

Loureiro SMC, Kastenholz E (2011) Corporate reputation, satisfaction, delight, and loyalty towards rural lodging units in Portugal. Int J Hosp Manag 30(3):575-583

Luo X, Bhattacharya CB (2006) Corporate social responsibility, customer satisfaction and market value. J Mar Sci 70(4):1-18

Maxham JGl, Netemeyer RG (2002) Modeling customer perceptions of complaint handling over time: The effects of perceived justice on satisfaction and intent. J Retail 78:239-252

Medina C, Rufín R (2015) Transparency policy and students' satisfaction and trust. Transf Gov People. Processes Policy 9(3): 309-323

Mittal S, Gera R, Batra DK (2015) An evaluation of an integrated perspective of perceived service quality for retail banking services in India. Int J Bank Mark 33(3):330-350

Mohr LA, Webb DJ, Harris KE (2001) Do consumers expect companies to be socially responsible? The impact of corporate social responsibility on buying behavior. J Consum Aff 35(1):45-72

Morgan RM, Hunt SD (1994) The commitment-trust theory of relationship marketing. J Mar Sci 58(3):20-38

Murphy PE, Laczniak GR, Wood G (2007) An ethical for relationship marketing: A virtue ethics perspective. Eur J Mark 41(1/2):37-57

Oliver RL (1999) Whence consumer loyalty? J Mar Sci 34(1):33-44

Orel FD, Kara A (2014) Supermarket self-checkout service quality, customer satisfaction, and loyalty: empirical evidence from an emerging market. J Retailing Consum Serv 21(2):118-129

Parguel B, Benolt-Moreau F, Larceneux F (2011) How sustainability ratings might deter "greenwashing": A closer look at ethical corporate communication. J Bus Ethics 102(1):15-28

Park SY, Levy SE (2014) Corporate social responsibility: perspectives of hotel frontline employees. Int J Contemp Hosp M Journal 26:332-348

Park J, Lee H, Kim C (2014) Corporate social responsibilities, consumer trust and corporate reputation: South Korean consumers' perspectives. J Bus Res 67:295-302 
Pérez A, del Mar García de los Salmones M, del Bosque IR (2013) The effect of corporate associations on consumer behavior. Eur J Mark 47(1/2):218-238

Reichheld FF (1996) Learning from customer defections. Harvard Bus Rev 74(2):56-69

Reynolds M, Yuthas K (2008) Moral discourse and corporate social responsibility reporting. J Bus Ethics 78:47-64

Roberts PW, Dowling GR (2002) Corporate reputation and sustained superior financial performance. Strategic Manage J 23:1077-1093

Roberts K, Varki S, Brodie R (2003) Measuring the quality of relationships in consumer services: An empirical study. Eur J Mark 37(1/2):1691-1696

Schmitz HP, Raggo P, Tosca BW (2012) Accountability of transnational NGOs: aspirations vs. practice. Nonprof Volunt Sec O 41(6):1175-1194

Shamsie J (2003) The context of dominance: an industry-driven framework for exploiting reputation. Strategic Manage J 24(3):199-215

Sirdeshmukh D, Japdig S, Berry S (2002) Customer trust, value, and loyalty in relational exchanges. J Mar Sci 66:15-37

Skarmeas D, Leonidou CN (2013) When consumers doubt, watch out! The role of CSR skepticism. J Bus Res 66(10):1831-1838

Smaiziene I (2008) Revealing the value of corporate reputation for increasing competitiveness. Econ Manage 13:718-723

Su L, Swanson SR, Chen X (2015a) Social responsibility and reputation influence on the intentions of Chinese Huitang Village tourists: Mediating effects of satisfaction with lodging providers. Int J Contemp Hosp M Journal 27(8):1750-1771

Su L, Swanson SR, Chen X (2015b) The effects of perceived service quality on repurchase intentions and subjective well-being of Chinese tourists: The mediating role of relationship quality. Tourism Manage 52:82-95

Su L, Swanson SR, Chinchanachokchai S, Hsu MK, Chen X (2016) Reputation and intentions: the role of satisfaction, identification, and commitment. J Bus Res 69(9):3261-3269

Sud M, VanSandt CV (2012) Of fair markets and distributive justice. J Bus Ethics 99:131-142

Swimberghe KR, Wooldridge BR (2014) Drivers of customer relationships in quick-service restaurants: The role of corporate social responsibility. Cornell Hosp Q 55:354-364

Vaaland TI, Heide M, Grønhaug K (2008) Corporate social responsibility: investigating theory and research in the marketing context. Eur J Mark 42(9-10):927-953

Waddock SA (2004) Parallel universes: Companies, academics, and the progress of corporate citizenship. Bus Soc Rev 109:5-42

Walsh G, Bartikowski B (2013b) Exploring corporate ability and social responsibility associations as antecedents of customer satisfaction cross-culturally. J Bus Res 66(8):989-995

Walsh G, Wiedmann K-P (2004) A conceptualization of corporate reputation in Germany: an evaluation and extension of the RQ. Corp Rep Rev 6(4):304-312

Walsh G, Mitchell WW, Jackson P, Beatty SE (2009) Examining the antecedents and consequences of corporate reputation: A customer perspective. Brit J Manage 20(2):187-203

Wan L, Poon P, Yu C (2016) Consumer reactions to corporate social responsibility brands: the role of face concern. J Consum Mark 33(1):52-60

Wang Y, Lo H-P, Hui YV (2003) The antecedents of service quality and product quality and their influence on bank reputation: Evidence from the banking industry in China. J Serv Theor Pract 13(1):72-83

Weiss AM, Anderson E, Maclnnis DJ (1999) Reputation management as a motivation for sales structure decisions. J Marketing 63(4):74-89

Wirtz J, Kum D, Lee KS (2000) Should a firm with a reputation for outstanding service quality offer a service guarantee. J Ser Market 14(6):502-512

Wu CH-J, Liao H-C, Hung K-P, Ho Y-H (2012) Service guarantees in the hotel industry: Their effects on consumer risk and service quality perceptions. Int J Hosp Manag 31(3):757-763

Zhang L, Mattila AS (2015) An examination of corporate social responsibility and processing fluency in a service context. J Serv Mark 29(2):103-111

Submit your manuscript to a SpringerOpen ${ }^{\circ}$ journal and benefit from:

- Convenient online submission

- Rigorous peer review

- Immediate publication on acceptance

- Open access: articles freely available online

- High visibility within the field

- Retaining the copyright to your article

Submit your next manuscript at $>$ springeropen.com 